\title{
Behind Transformation: The Right to Food, Agricultural Modernisation and Indigenous Peoples in Papua, Indonesia
}

\author{
Irene I. Hadiprayitno
}

Published online: 14 March 2015

C The Author(s) 2015. This article is published with open access at Springerlink.com

\begin{abstract}
The norms and ideals of human rights are increasingly invoked by civil society organisations to construct claims related to land tenure and access to food, particularly to challenge a massive expansion of agricultural investment in a developing country. While this has facilitated negotiations on rights and the formulation of claims, studies that investigate to what extent such endeavours achieve the transformational goals advocated by human rights proponents or in particular whether they have been successful in instigating any institutional reform in the governance of massive agricultural modernisation projects are scanty. After discussing a national agricultural modernisation project, the Merauke Integrated Food and Energy Estate (MIFEE), set up in Merauke, Papua, the article concludes that the analysis of the transformative role of human rights requires a prudent examination of the role of the State in the negotiation process, the patterns of socio-cultural interactions signifying the political setting and the pressure experienced and perceived by actors that affect the issues selected and omitted.
\end{abstract}

\section{Introduction}

All seemed to be well at first as a number of human rights activists traversed the Kumbe River and continued snaking on a motorbike through the rain forest in Merauke, Papua, Indonesia. It was only after at least $3 \mathrm{~h}$ of travelling that a security post was spotted, in front of which was a long horizontal forest gate, suggesting that it was an entrance to a separate territory. Thereafter, the view was not the same: a long, empty, mangled, and burned land stretched into the distance. This change in what can be seen on the horizon is a sign that the Merauke Integrated Food and Energy Estate (MIFEE), a national agricultural modernisation project launched in 2010, has begun to take full effect in the village Zanegi. With

I. I. Hadiprayitno $(\square)$

International Studies, Leiden University, Leiden, The Netherlands

e-mail: irehadi@gmail.com 
a powerful slogan 'Feed Indonesia and Feed the World', the project aims to achieve food security by increasing food production and safeguarding food availability, which is the reason why activists from civil society organisations in Jakarta, Jayapura and Merauke came to Zanegi village to collect information and provide human rights training for the villagers.

As a global phenomenon, agricultural modernisation executed through massive land acquisition is considered to be one of the results of the global rise of food prices in 2008. While the data varies, the scope and speed of massive land acquisition are vast. According to the International Land Coalition (ILC), 80 million hectares have been taken since 2001. The World Bank published figures stating that 56 million hectares were released between 2008 and 2009 (Deiniger et al. 2011). In 2012, GRAIN reported that there were 416 instances of largescale land acquisition, which comprised nearly 35 million hectares in 66 countries. One common feature is that multinational corporations execute massive permanent or temporary land acquisition in wealthier countries or the developed world, with the purpose of exporting agriculture and producing biofuels made by wealth funds and multinational corporations based in wealthier countries or developed world. Although some argue that this brings a winwin solution resulting from the development opportunity-the injection of much-needed investment into the agricultural and rural development of poor developing countries - there are concerns about the impact of agricultural modernisation on indigenous peoples, who risk losing their access to and control over land on which their livelihood depends.

Repressed by the impacts of agricultural modernisation projects, local communities, including the indigenous peoples of Merauke, and personnel in civil society organisations have invoked human rights discourses to frame their struggles to have access to and control of land. However, amid the increase of this endeavour, the question remains to what extent it has a transformative role-whether it has been successful in delivering change and instigating reform in the governance of massive agricultural modernisation.

This paper critically analyses the negotiations of human rights and the right to food in Merauke, Papua, Indonesia, as observed during several field visits in 2011. It investigates the complexities that constitute modern challenges to implementing human rights and especially the right to food in the governance of access to food and land for indigenous people. How are norms on human rights and the right to food being referred to in the struggles that address land acquisitions? How do different individuals and institutions use norms on human rights and the right to food in particular to contest or to design law, norms and policies on indigenous land access? What kind of values and meanings are given to the right to food and what are the consequences? To answer these questions, the article is structured as follows. First, legal and social theories on the transformative role of human rights and the right to food are explained. Second, the contemporary challenges for governing agricultural modernisation in Merauke, Papua, Indonesia are discussed. Then, the process of negotiation over human rights is analysed by assessing the economic and political complexities of realising the transformative potential of human rights and the right to food. Concluding remarks are provided at the end. 


\section{Theoretical Observations on the Transformative Role of Human Rights and the Right to Food}

\section{Human Rights, the Right to Food and Agricultural Modernisation}

The right to food is asserted in Article 11 of the International Covenant on Economic, Social and Cultural Rights (ICESCR), which encompasses 'the right of everyone to an adequate standard of living for himself and his family, including adequate food'. Another legal basis for the right to food is found in Article 1(2) of the International Covenant on Civil and Political Rights (ICCPR), which states that 'in no case may a people be deprived of its own means of subsistence', and in Article 6: 'every human being has the inherent right to life'. The articles assert the fundamental entitlement to what is needed to sustain life, including having adequate food and being free from hunger.

In the General Comment No. 12, the Committee on Economic, Social and Cultural Rights concluded that the 'core content' of the right to adequate food implies the need to ensure 'the availability of food in a quantity and quality sufficient to satisfy the dietary needs of individuals, free from adverse substances, and acceptable within a given culture', and 'the accessibility of such food in ways that are sustainable and that do not interfere with the enjoyment of other human rights'. Moreover, the human right to food also encompasses the entitlements to physical and economic access to adequate food or means for its procurement, as asserted in paragraph 6 of the General Comment No. 12. In this regard, individuals can secure access to food (a) by earning incomes from employment or self-employment; (b) through social transfers or (c) by producing their own food, if they have access to land and other productive resources. ${ }^{1}$

As any other human rights, these entitlements are subject to the state as the main duty bearer with the obligation to respect, protect and fulfil. State parties to the ICESCR are required to take steps to move 'as expeditiously as possible' towards realising the right to adequate food, known as the principle of progressive realisation. Article 2(1) of the ICESCR further asserts the state parties should take 'the maximum of its available resources, with a view to achieving progressively the full realisation of the rights recognised in the present Covenant by all appropriate means, including particularly the adoption of legislative measures'. Furthermore, the General Comment No. 12 on the right to food stipulates that the formulation and implementation of national strategies for the right require compliance with the principles of accountability, transparency and people participation, among others. ${ }^{2}$

With regard to the debate on agricultural modernisation and large-scale acquisition, the right to a food framework is argued to contribute important lessons. Paragraph 13 of the General Comment No. 12 emphasises that special attention must be paid to 'socially vulnerable groups such as landless persons or indigenous people' and 'indigenous population groups whose access to their ancestral lands may be threatened'. To elucidate the significance of that paragraph, the Special Rapporteur on the right to food, Olivier de Schutter, explains ${ }^{3}$ :

\footnotetext{
${ }^{1}$ Committee on Economic, Social and Cultural Rights, General Comment No. 12 on the Right to Adequate Food, U.N. Doc. E/C.12/1999/5 (1999), paras. 6, 7 and 17.

2 Ibid, para. 23

${ }^{3}$ Human Rights Council, Report of the Special Rapporteur on the Right to Food, Large-scale land acquisitions and leases, A/HRC/13/33/Add.2 of 28 December 2009, para. 33.
} 
The arrival of investors in agriculture may present certain opportunities, but there are also important human rights challenges, and investments that can affect land rights are a particular source of concern. The human right to food would be violated if people depending on land for their livelihoods, including pastoralists, were cut off from access to land, without suitable alternatives; if local incomes were insufficient to compensate for the price effects resulting from the shift towards the production of food for exports; or if the revenues of local smallholders were to fall following the arrival on domestic markets of cheaply priced food, produced on the more competitive large-scale plantations developed thanks to the arrival of the investor.

Furthermore, de Schutter optimistically advocates the transformative role of the right to food. In his final report as the Special Rapporteur, ${ }^{4}$ he refers to the contribution of the right to food particularly in highlighting the fragmentation and power imbalance of the global food system and in providing the basis for formulating global food policies. Eradicating hunger requires a combination of empowering local communities, implementing supportive national policies, and creating an enabling international environment that can affect the ability of countries to guarantee the right to food.

Notably, empowerement is the first condition for realising the right to food. In practice, this implies the first action 'at the local level to identify the obstacles that they face and the solutions that suit them best'. To achieve results, however, the action must be complemented by 'supportive policies at the national level that ensure the right sequencing between the various policy reforms that are needed, across all relevant sectors, including agriculture, rural development, health, education and social protection'. ${ }^{\circ}$

In this vein, the Special Rapporteur ties the transformative role of the right to food with policy formulations on large-scale land acquisitions. The invocation of the right to food would be able to address complexities in decision making policies. This implies that in addition to facilitating the identification of needs of a community, particularly by the rights-holders themselves, the right to food also has a fundamental importance in designing accountable policies and creating an enabling environment. The academic debate on the transformative role of human rights is rather distinct. As a subject of academic scrutiny, many scholars have coined and used various analytical frameworks to explain the link between the role of human rights and the complex realities where rights-holders activate and invoke human rights norms.

\section{The Transformative Role of Human Rights}

Academic studies copies on how human rights have been invoked and their corresponding potential are centred on discussing problematics in realising a number of normative points contained in international human right law with regard to people's legal entitlements and state obligations. As global acknowledgement of human rights

\footnotetext{
${ }^{4}$ Human Rights Council, Report of the Special Rapporteur on the right to food: The Transformative Potential of the Right to Food, A/HRC/25/57, 24 January 2014

${ }^{5}$ Ibid, para. 50, p. 20.

${ }^{6}$ Ibid.
} 
norms is often confined to international workshops, seminars or meetings at grassroot level, these norms need to be interpreted as legislative measures as well as good practices in designing and executing policies. Mechlem (2004, 643-645) writes that projects and policies designed in the light of the right to food should be distinctive in their methods and objectives, particularly in accountability, transparency and participation. Nonetheless, since realistic obstacles with regard to the political economic structure of various systems of governing access to food remain, it is necessary to address these particular challenges (Mowbray 2007, 568). In this regard, setting out the right to food in a negotiation process should aim to give vulnerable societies greater control over resources, thus approaching human rights as having not only a protective role, but a transformative one. Implied here is an assumption that the invocations of rights through claims and representations will enable rights-holders to form resistance groups, and to challenge power hierarchies and political configurations - or in other words to instigate institutional change (De Gaay Fortman 2010; Risse et al. 1999; Rajagopal 2003, 45).

Carpenter and Riley $(2014,177)$ observe that to identify a transformative way for indigenous peoples to invoke human rights, one needs to examine situations where the rights-holders are participating in human rights movements and influencing the law around and outside their communities all the way up to state and international arenas. Once regarded as a tool for imperial power and conquest, international law has begun to change its shape and function. For example, the human rights principle of selfdetermination has been increasingly employed to 'uncover' the legal traditions of indigenous peoples and to 'decolonialise' indigenous experiences. The growing body of international human rights law activists on indigenous rights is advocating that different actors, e.g. legislatures, agencies and other organs in civil society, should take a nuanced approach to human rights. The growing number of norms and principles on rights and obligations has been matched by the need for contextual and functional interpretations in various fora, including tribal courts or states and international tribunals. Here, invoking legal norms requires legal mobilisation tactics that shape the political strategies of these courts and tribunals (Morgan 2009, 130).

Notably, the process rather than the result of the process is the key to understanding the transformative role of human rights. Goodale $(2007,8)$ considers human rights not simply as norms, rather as the means through which the idea of human rights becomes discursive. Rendering human rights into social knowledge that shapes social practices is of interest here. Social practices become fundamental to the idea of human rights, rather than simply the testing ground on which the idea of universal human rights encounters actual social or legal systems. As a result, everyday practices are the spaces in which actors operationalise the term of references of human rights norms, rules and principles to mediate social, economic and political relations. They are assumed to create new conditions with which individual and groups can organise resistance (Goodale 2007, 130).

In practice, the development of human rights norms has introduced the idea that individuals and groups are entitled to organise themselves in ways that respect their dignity and diversity, rather than impose a normative homogeneity of meanings and values. Merry (2006, 44-47) further coins the social practice of negotiating human rights with the concept of vernacularisation, which can be categorised into replication and hybridisation. Replication is the process where human rights claims are implanted 
in a cultural context with very little attempt at modification. Replication retains the basic structure of the imported institution. Here, the source, i.e., the original formulations of legal norms and institutions, is relatively dominant, whereas in hybridisation, the target is more powerful. Hybridisation merges local structures such as councils with imported ideas, such as the right to food. Upon examining the local use global woman's right in Peru, China, India and the USA, Levitt and Merry (2009) consider vernacularisation as a cultural act, which requires an analysis of socio-cultural underpinnings.

The key actors to the process of vernacularisation are people in the middle, those who work in civil society organisations (Merry 2006, 39). Their positioning, loyalties, commitments and knowledge of both sides (as rights-holders and duty-bearers) are considered to be the factors that can shape vernacularisation processes. Civil society organisations have the capacity to translate the discourses and practices from international law and legal institutions to specific situations of suffering and violations. Moreover, they also have an important role in domestic-transnational coalitions (Keck and Sikkink 1998), with regard to their capacity to form a network that challenges a global vs. a local dichotomy. Topidi and Fielder (2013) understand such a network as a cross-border collective action, which must be added to the list of formations likely to promote compliance of state institutions with universal norms and therefore also the legitimacy of the norms.

Scholars have examined how a reference to human rights in the process of negotiations serves to clarify people's positions in protests and forms of resistance and their expectations (Rajagopal 2003, Baxi 2002). There is a huge symbolic significance in the right to food, and the importance of declaring an entitlement to adequate food to be a human right. The existence of such a right and its corresponding action emphasises the political function of human rights to assist in articulating claims (Mowbray 2007, 566). The concept of hunger, for example, might have a different meaning if one assigned to it the attributes of the human right to food or nutritious dietary intake. At the same time, this can act as a process of empowerment, enabling people to connect their interests with legitimate and claimable rights.

A reference to human rights in the social process of negotiation can be an act of power, too, especially when it involves reinterpreting one set of experiences and categories in the terms of another powerful one. According to Kennedy (2002), this entails framing the stories differently from the way the victims do in order to underline misconduct and failures pragmatically. Increasingly, those in social movements involved in advocacy work on development projects invoke human rights as a political choice (Golan and Orr 2012, 790). It is expected that the target actors, such as states, may be more responsive to demands based on the claims of victimhood (Meister 2002). Moreover, those in civil society organisations may also think that posing a problem this way will resonate more with their potential constituents, and help them pursue their goals more effectively. They may think they will raise more funds, particularly from international organisations and foundations. They may also think that such references to international legal norms and discourses imbue their organisation with an air of global connectedness, modernity and progress (Levitt and Merry 2009, 443). One or a combination of these reasons makes it easier for them to build networks with and obtain responses from formal state institutions and other international organisations.

Thus, those running civil society organisations often have an ambivalent view of the law in general, seeing it not only as a force for maintaining the status quo and 
domination that must be contested or ignored, but also as a mechanism that provides a space for resistance (Rajagopal 2005, 183). The human rights movement promises that 'law' - the machinery, the texts, the profession, the institution - can resolve conflicts and ambiguities in society by resolving those within its own materials, and that can be done on the basis of a process of 'interpretation', which is different from, more legitimate than, politics (Kennedy 2004, 22). In this regard, critical scholars reason that in some contexts the dominance of human rights weakens the possibility of effective struggle through more 'political' means and prevents more radical demands for change by normalising power relations (Brown 1995, Hale 2002). While rights talks may operate as a force for transformation and emancipation at one moment of history, at another time of a historical and regulatory discourse, they may also become a means of obstructing more radical political demands, or simply hollow, empty promises (Golan and Orr 2012, 791). Rights and interpretations of rights are converging with powers of social stratification and lines of social demarcation in ways that extend as often as attenuate these powers and lines.

\section{Positioning MIFEE and Agricultural Modernisation Debates in Indonesia}

In August 2010, MIFEE was launched with a view to developing a plantation of 1.2 million hectares for cash crops and biofuels in Merauke, Papua, Indonesia. The Indonesian government foresees that by 2020, the region will produce 1.95 million tons of rice, 64,000 cows, 2.5 million tons of sugar, 167,000 t of soybean, 2.02 million tons of maize, and 937,000 tons of crude palm oil annually. The project will be developed in stages, from 2010 to 2014, 2015 to 2019 and 2020 to 2030. Furthermore, 44,900 jobs in the agricultural sector for indigenous peoples and transmigrants will be created, leading to an increase of income of up to US\$13,500 per household per year. ${ }^{7}$ MIFEE is designed as an integral part of the Master Plan for Acceleration and Expansion of Indonesian Economic Development formally launched by President Susilo Bambang Yudhoyono through the adoption of the Presidential Decree No. 32 of $2011 .^{8}$ The Master Plan, also known by the acronym MP3EI, will lead to Indonesia becoming one of the top ten major economies in 2025. The plan has three main strategies: to develop the six national economic corridors, ${ }^{9}$ to speed up the development of human resource capacity, and to stimulate innovation through national science and technology that will feed into the long-term support of such accelerated economic development.

The government has pinpointed specific development themes for each economic corridor. Sumatra will be the centre for producing and processing natural resources and the nation's energy reserves. Java will continue to act as the driver of national industry and service provision. Kalimantan will be the centre for producing and processing national mining and energy. Sulawesi has the potential to develop national agriculture,

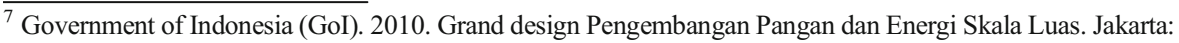
Ministry of Agriculture

${ }^{8}$ Government of Indonesia (GoI). 2011. Master Plan for Acceleration and Expansion of Indonesian Economic Development. Jakarta: Ministry of Economic Affairs.

${ }^{9}$ These economic corridors are Sumatera, Java, Kalimantan, Sulawesi, Bali-Nusa Tenggara, and PapuaMollucs.
} 
plantations, fisheries, and oil and gas mining. Bali and Nusa Tenggara will remain gateways for tourism and national food support. This is particularly connected to the plan intended for Moluccas and Papua, which are to be the centres for food, fisheries, energy and mining. The corridor is an ideal space of arable land, divided into eight economic centres. To investors, the Moluccas and Papua economic resources presents an opportunity for agricultural expansion.

Specifically, Merauke is a designated area for food and energy reserves in East Indonesia, because of its flat geographical terrain and fertile terrain. The MIFEE project will be executed by establishing ten clusters of agricultural production centres ${ }^{10}$; at least 36 companies have acquired operational permits to be involved in the implementation. The project aims to establish a central production area for food crops, horticulture, animal husbandry, fisheries and plantations by 2030. There are plans to produce rice, corn, soybeans, sorghum, wheat, vegetables and fruit, and the livestock for animal husbandry will include chicken, cows, goats and rabbits. The programme also aims to support productive plantations of sugar cane, rubber and palm oil.

Like any other development projects in the age of globalisation, public-private partnership is the main buzzword among decision makers and legislators. While the government of Indonesia is playing a decisive role in the MIFEE project, private investments (both foreign and domestic) are fundamental to the expansion and acceleration of economic development. ${ }^{11}$ The Indonesian government has limited funds to finance development through its state budget (Anggaran Pendapatan dan Belanja Negara; APBN); therefore, according to the MP3EI, $44 \%$ of the total investment is expected from private actors and industries. Hence, all existing regulatory frameworks must be evaluated, and strategic steps must be taken to revise and change regulations in order to attract investors.

To ensure more incentives on tariffs, taxes, import duties, labour regulations, licensing and permits and land procurements are being implemented for investors, the government has issued various legislations. Law No. 41 of 2009 allows local and foreign private investors to participate in the production and trade of agriculture products for domestic and export markets. ${ }^{12}$ Government Regulation No. 18 of 2010 on cultivation of plants grants the limit of foreign investments up to $49 \%$. The most recent law is Law No. 2 of 2012, on land acquisition for development and public interests, which asserts a simplified procedure with regard to land acquisitions and the distribution of compensation and therefore is observed as to provide more security for

\footnotetext{
${ }^{10}$ The short-term development priority of MIFEE (2011-2014) is to develop clusters I to IV, covering an area of 228,023 ha. The four clusters being developed are the following: Greater Merauke, Kali Kumb, Yeinan and Bian located in the Merauke Regency. The medium-term (2015-2019) expansion will be directed at developing areas of agricultural production centres for food crops, horticulture, animal husbandry, plantation and aquaculture in Clusters Okaba, Ilwayab, Tubang and Tabonji.

11 The total investment required for the six corridors is IDR 4012 trillion. From this total, it is expected that the Sumatra Corridor will receive IDR 714 trillion (18\% of total investment), the Kalimantan Corridor will receive IDR 945 trillion ( $24 \%$ of total investment), the Java Corridor will receive IDR 1290 trillion (32\% of total investment), the Sulawesi Corridor will receive IDR 309 trillion ( $8 \%$ of total investment), the Bali-Nusa Tenggara Corridor will receive IDR 133 trillion (3\% of total investment) and the Papua-Kepulauan Maluku Corridor will receive IDR 622 trillion (15\% of total investment).

${ }^{12}$ Before 2009, the government issued several laws and regulations that supported the privatisation of agricultural modernisation. For instance, Law No. 41 of 1999 on forestry, Law No. 18 of 2004 on plantation, Law No. 7 of 2004 on water resources, a law in 2005 on agricultural revitalisation, Law No. 25 of 2007 on investment, and Law No. 4 of 2009 on mineral and coal (Minerba).
} 
investors regarding land acquisitions (e.g. Sumardjono 2012). These legal sources will increase the flexibility for investors to operate and at the same time ensure there are fiscal facilities for foreign capital to secure contracts and concessions on land and natural resources in Indonesia.

There is a wide-ranging debate on the political and economic considerations of the MIFEE project in Merauke, Papua, one of which has a decentralisation perspective. The expansion of agricultural production in Papua can be explained by how finance is organised in this region compared with other regions. In Indonesia, decentralised regional governments are under financial pressure to fund the daily organisation of their regions. The status of special autonomy of Papua comes with a development fund granted for 25 years, from 2001 to 2026 . The idea of promoting massive expansion of agricultural enterprises in Papua has therefore been argued by the central and local governments as being a logical process. Profits deriving from MIFEE are said to secure funds necessary for the development process in Merauke.

However, this objective is not without challenges. Intervention in the form of development funds with special autonomy status has not significantly improved the quality of public services and infrastructure. In fact, many researchers have reported that decentralisation in Indonesia has led to political contests between elites over their authority to manage local resources (Aspinall and Fealy 2003, Hadiz 2004, Davidson 2009). Researchers Indonesian Academy for Science (Lembaga Ilmu Pengetahuan Indonesia; LIPI) observe that in Papua, the most striking change since special autonomy came into effect has been the increase in the amount of development funds, rather than any actual autonomy (Widjojo 2010). Money drawn from the Special Autonomy Fund has merely been used to finance bureaucratic facilities in the new agencies. At the same time, the central government maintains its opinion that granting more authority in the region would provide a larger space for the hidden agendas of the separatists (Chauvel and Nusa Bhakti 2004). As a result, there is not yet a new paradigm for development processes that would genuinely empower people in Papua, hold the bureaucrats in Papua accountable, and change the paradigm with regard to the position of Papua in Indonesia. Nonetheless, the dominant capital flows for development - the people of Papua in rural and urban areas - are still just spectators, particularly as there is not yet any policy that is truly directed at the interests of indigenous peoples (Widjojo 2010, 94).

Furthermore, there are lingering questions regarding income sustainability derived from the MIFEE project. Arguably, there is no single and reliable calculation for the amount of government revenues generated from MIFEE. If the distribution of benefits is organised according to the procedure regulated for the exploitation of natural resources, such as forest or peat land, under Law No. 21 of 2001 on Special Autonomy, Papua will receive roughly $80 \%$ of the funds. If it follows the sharing export revenue based on the Roundtable of Sustainable Palm Oil (RSPO) scheme, Merauke's share of these financial resources would be US\$62 million annually over the same period from US\$166 million in annual revenues for the Indonesian government based on 1 million hectares of palm oil plantations (for the purpose of calculation). The amount would be generated over the first 7 years. In subsequent years, the total revenue would decline sharply to US\$7 million annually, and Merauke's share of this would be US\$2 million (Obidzinski et al. 2013).

Many who observe the progress of the MIFEE project fear disasters may follow the removal of financial support from Jakarta and MIFEE as the substitute. Massive 
development projects that involve a considerable appropriation of traditional land would bring significant social and economic challenges, especially for indigenous people. Using qualitative research conducted in two villages in Merauke, Zakaria et al. (2011) identified socio-cultural problems, demographic revolutions, and economic and political marginalisation as the main detrimental effects of MIFEE. ${ }^{13}$

The emphasis on investments relying heavily on private actors and industries has the potential to reshape and redefine the governance of access to food and land resources. As new actors, in particular private ones, are introduced, negotiations of rights and obligations of rights-holders and duty-bearers bring different strategies and goals. Civil society international and national non-governmental organisations involved in reshaping and redefining the relationship between the regional government and the people of Merauke as rights and obligations respond to this situation.

\section{Negotiating the Right to Food in the Struggles against MIFEE}

As mentioned before, the transformative role of human rights is linked with the ways human rights are negotiated at grassroots level. It is crucial to identify the complexity of food systems and the needs of the community. Furthermore, to achieve its transformative ideals, the invocation of human rights should focus on challenging, if not changing, the power relationships between individuals and the state. In this regard, one needs to assess how and the extent to which the negotiation of human rights relates to the formulation of accountable policies and the creation of an enabling environment.

In addition to the political economy consideration that establishes Papua as a strategic area for the MIFEE project, agricultural modernisation in Papua is arranged within at least three legal frameworks. The first is the human rights legal framework. The ratification of the two human rights covenants and the adoption of Law No. 39 of 1999 by the Indonesian government imply that the right to food has a legal standing in the court of law. However, this law has to be read in conjunction with Law No. 26 of 2000 on human rights courts, which asserts the jurisdiction of the ad hoc human rights court to hear only cases of gross violation of human rights - those of genocide and crimes against humanity. The right to food hence has no legal standing in Indonesian human rights courts. This discrepancy creates an area of uncertainty on the promotion and protection of the right to food in the governance of the food system (Hadiprayitno 2010).

The second legal framework is the MIFEE legal framework, which includes Law No. 41 of 2009 on the protection of sustainable agricultural land, Presidential Decree No. 32 of 2011 on the acceleration and the expansion of economic growth, and Law

\footnotetext{
${ }^{13}$ Zakaria et al. (2011) argue that these impacts include the low level of education of Papuans, and their hunting and gathering mode of production, which will exclude them in the transformation from household farming to corporate-mechanisation farming (the socio cultural gap). The labour demand of corporate farming is calculated to absorb about 4.8 million new migrants from outside Papua, which will leave Papuans as only $5 \%$ of the total residents. This demographic change will displace Papuans from having access to economic power, as experienced by the Papuans during a transmigration program in the 1980 s (demographic revolution). Agricultural modernisation that provides no space for Papuans will further the socioeconomic polarisation, leaving Papuans at the lowest level of the economic ladder (economic marginalisation). The greater economic power that will be better accessed by migrants than native Papuans may also bring migrants better access to political power as well in government offices and other forms of political leadership (political marginalisation).
} 
No. 2 on land acquisition for development. As argued before, these are the predominant legal sources defining the governance of land acquisition in Merauke, Papua, and are intended to secure private investments. ${ }^{14}$

Third is the customary legal framework. Customary claims on land tenure are arranged under Ministry of Agraria Regulation No. 5 of 1999, which instructs regional governments to research claims of the recognition of customary communal land and record their findings in regional regulations. Under the 1945 Constitution, Article $18 \mathrm{~B}(2)$ recognises and respects individual customary law communities, insofar as they are 'still alive' and 'in line with' the evolution of society and the unitary state and national law. Article 28i(3) moreover asserts the protection of cultural identity and rights of traditional communities in accordance with changing times and culture. A limitation to the realisation of indigenous rights to land is found in Article 67(1) of Law No. 21 of 2001 on the special autonomy of Papua, which asserts that the customary claims regarding control over lands and property can only be established if they are found to be 'still relevant' and do not conflict 'with national interests'. ${ }^{15}$

Unlike these three legal frameworks, global human rights norms and principles have acquired a dominant position in the process of negotiating access to food and land in Merauke, Papua. The right to food and human rights norms and discourses, particularly as asserted in international legal norms and discourses, are employed by about 22 civil society organisations, which are currently involved in the MIFEE network, providing a wider range of advocacy work. Workshops and other forms of training are common advocacy methods and the key sites for vernacularisation processes for at least two reasons. In these sites, knowledge of human rights norms and principles can be transferred from human rights activists to citizens, and these sites also provide an opportunity to share experiences and grievances. Workshops and other forms of training consequently allow a mutual exchange of discourses and practices to take place, a model of communication required for both parties to frame their understanding of human rights. The result of these events is presented in the formulation of claims and plans for actions, which can take the form of human rights reports. At least three human rights reports and requests have been written and submitted to the international community on MIFEE.

In August 2011, a request for urgent assistance to address the imminent threat to the right to food of the indigenous peoples in Merauke, Papua Province, Indonesia, was sent to the UN Special Rapporteur on the Right to Food. ${ }^{16}$ The letter emphasises the acts and omissions committed by the government of Indonesia that have a negative impact on people's access to food and their ability to feed themselves. Paragraph 9 of the letter reads as follows:

\footnotetext{
${ }^{14}$ Other legal sources for legitimating land acquisition in Indonesia are Law No. 41/1999 on forestry law, Law No. 26/2007 on spatial planning, and Government Regulation No. 26/2008 on national territory spatial planning. In particular, Law No. 41 of 1999 on forestry allows the state to create a massive system of publicly and privately held forestry concessions in the forests traditionally owned by indigenous peoples without any regard for their rights or existence.

${ }^{15}$ The Forestry Department claims that the state has jurisdiction over $72 \%$ of land (Bakker and Moniaga 2010, 189).

${ }^{16}$ Request for Urgent Assistance to Address the Imminent Threat to the Right to Food of the Indigenous Peoples in Merauke, Papua Province, Indonesia. Submitted by Sawit Watch and Forest People Program, 9 August 2011.
} 
To date, indigenous Papuans (to which the Marind and other Merauke indigenous peoples belong) already have lost a considerable area of their traditional territories due to logging, mining, oil palm plantations and population transfers. They have received few benefits and suffered severe negative impacts, which, in many cases, amount to irreparable harm. These operations have the full support of the State in Indonesia, at all levels, and frequently enjoy the protection of the Indonesian Army. The MIFEE Project is in direct contradiction to the affirmation by the UN Committee on Economic, Social and Cultural Rights".

In elucidating how the project is in direct contradication to the ICESCR, it argues that the right to food is being violated as '[s]ocially vulnerable groups such as landless persons and other particularly impoverished segments of the population may need attention through special programmes'. ${ }^{17}$ The report further emphasises a 'particular vulnerability [to the exercise of the right to food] is that of many indigenous population groups whose access to their ancestral lands may be threatened' ${ }^{18}$

A slight different wording is observed in the Request for Consideration of the Situation of Indigenous Peoples in Merauke, Papua Province, Indonesia, submitted to the Committee on Elimination of Racial Discrimination in September 2011, which refers to indigenous rights and self-determination principles to describe the gravity of the situation ${ }^{19}$ :

Agro-industry in Indonesia, such as the MIFEE project, is highly detrimental to indigenous peoples and this has been widely acknowledged. Indonesia, however, continues to disregard its obligations and is now massively expanding agro-industry operations into Papua, the territories of the most vulnerable and discriminated against indigenous peoples in that country. The subject of this request, the MIFEE project, is emblematic of this expansion and the drastic and extreme impacts on the affected indigenous peoples, whose survival as distinct cultural and territorial entities is gravely and imminently threatened. Without urgent and sustained international scrutiny and attention, they may cease to exist as collective entities altogether in the coming years.

A group of civil society organisations concerned about the impact of cash crops and biofuel plantations on indigenous people's rights to land also raised the issue of MIFEE in their Stakeholders' Submission to the 13th session of the Human Rights Council's Universal Periodic Review in November 2012. ${ }^{20}$ Their report presents evidence of the continued neglect of the right to land, territories and natural resources of rural communities and particularly indigenous peoples by the government of Indonesia. Drawing on several cases in Kalimantan, Sulawesi, Sumatera and Papua, it was observed that such neglect has increasingly worsened in the implementation of policies and practices of natural resource

\footnotetext{
17 Ibid.

18 Ibid.

${ }^{19}$ Request for Consideration of the Situation of Indigenous Peoples in Merauke, Papua Province, Indonesia, under the United Nations Committee on the Elimination of Racial Discrimination's Urgent Action and Early Warning Procedures. Submitted to United Nations Committee on the Elimination of Racial Discrimination, 79th session, 8 August-2 September 2011

${ }^{20}$ Stakeholders' submission to the 13th session of the UPR Working Group (21 May-1 June 2012). Joint report submitted on 21 November 2011 by several civil society organisations, namely HUMA, Pontianak Institute, Down to Earth, Pusaka, Walhi, AMAN, Forest People Program, KKI Warsi, YMP and RFN.
} 
exploitation and climate change impact mitigation in the last 4 years. Writing about MIFEE in Merauke, Papua, paragraph 21 of the report states the following:

The documented negative impacts of MIFEE include coercion and manipulative practices to obtain certification that indigenous peoples have relinquished their land; increased inter-ethnic conflict and violence; and the clearance of the forests on which the Marind and other indigenous communities depend on directly and almost entirely for their subsistence, in order to make way for monocrop plantations under long-term leasehold contracts between the state and private companies. Violations associated with the MIFEE project also include the violation of rights of free assembly, speech and the right of freedom from threats to one's physical integrity.

In particular, the submission of the Stakeholder's Report aims to provide information on the level of compliance of the government of Indonesia to the recommendation made by the Human Rights Council during Universal Periodic Review (UPR). ${ }^{21}$ In formulating the claim, the Stakeholder's Report refers especially to Paragraphs 77 (5) and (7), Paragraph 78 of the UPR Working Group report which recommend the government of Indonesia to continue measures to promote and protect the human rights of all components of the Indonesian people.

The three reports show the role of global human rights norms in the formulation of claims. While the reports also refer to the national law and regulations that do not help protect people from the impact of MIFEE, ${ }^{22}$ human rights laws, particularly international human rights principles and norms, are invoked prominently to explain the infringements conducted by the state. The excerpts from the reports above reveal the focus on indigenous identity and the attributes surrounding it. In these reports, the core problem is beyond the question of law enforcement, rather it is about justice making as a distinctive problem embedded within the indigenous identity of the victims and the rights-holders.

Notably, the process of vernacularisation occurs as a process of replication, which implies there is an emphasis on and a dominant role of the source, i.e. the global norm on the right to food. The process also occurs not in a translation or a linguistic logic, in the sense that it expands or reinterprets the substantive content of the right to food. Nor has the right been used in conjunction with national legal, political or economic aspects of the project. Rather, it occurs in the prudent demonstration of challenging realities faced by indigenous people to secure their access to food and the ability to feed themselves. The strategy provides a prescription for the efforts and responses being demanded by the state. Recognition of the distinct cultural and territorial entities in combination with a reference to international norms on the right to food has imbued the negotiation process with a sense of global connectedness. Moreover, reference to indigenous identity provides a rooted elucidation of the detrimental impacts of agricultural modernisation as well as contextualisation necessary to elevate the negotiation of the right to food from the local to the global arena. And as an act of power, the

\footnotetext{
${ }^{21}$ Human Rights Council, Universal Periodic Review. Report of the Working Group on the Universal Periodic Review. Indonesia, A/HRC/8/23, 14 May 2008

${ }^{22}$ See Request for Consideration of the Situation of Indigenous Peoples in Merauke, Papua Province, Indonesia, under the United Nations Committee on the Elimination of Racial Discrimination's Urgent Action and Early Warning Procedures, United Nations Committee on the Elimination of Racial Discrimination, 79th session, 8 August-2 September 2011, Paras. 18-23.
} 
written reports demonstrate that the contentions that might occur in the process of defining the entitlements and duties can be reconciled.

The latter is observably arduous when one examines actual struggles and formulated claims at grassroots level. Numerous actors are involved in these domains, a circumstance that creates different ways of organising competitions and interests. Some actors are more influential and present in everyday life. The state, represented by the local and district government of Merauke, is recurrently absent in negotiations, or at least its main task is noticed as an initial facilitator. Civil society organisations show considerably more presence than the state, yet the access acquired by private actors and companies in the everyday life of the community is peerless. As a result, anchoring claims to formal sources as international human rights norms and principles is a calculated choice in such sites.

The negotiation on the financial compensation for the acquisition of indigenous land in Zanegi village by Selaras Inti Persada Inc. can provide an illustration. Negotiations have taken place since 2007 in this village. ${ }^{23}$ Meetings between the company and head of marga (clans) were initially facilitated by the Head of District Animha, Merauke, whose authoritative influence could forestall resistance. The outcome was what the population called 'a dowry' of IDR 300 million (down from the initial demand of IDR 1.2 billion) (2) $^{24}$ to given to each of the marga in exchange for 'the permission' given to the company to exploit Zanegi's indigenous forest. Another financial note attached to the agreement is that during its operation, the company will be considered to 'buy' the original timber it extracted from the forest. The land remains Zanegi's 'indigenous property'.

When asked why financial compensation to land acquisition had taken the form of a 'dowry', the representative of the company claimed it was a constitutive part of the company's commitment to 'corporate social responsibility'. Seralas Inti Persada Inc. employed the terms 'tali asih' (compassionate agreement) and 'piagam penghargaan' (appraisement plaque) to label and describe the arbitrary output of negotiations. It is perceived that these terms are suitable to express the company's unaccountable appreciation of their relationship with the Zanegi villagers. They are also chosen to symbolise the company's highest appreciation of cooperating with the village people and as a euphemism for its inability to compensate for the loss of indigenous lands' spiritual value. In addition to the financial compensation being distributed among the clans, the agreement is also manifested in the company's commitment to developing village infrastructures and social facilities, such as a school, church, village office, cultural centre, electricity generator, water provider facility and connecting roads. Other assurances were mentioned as well, such as providing a salary for school teachers and employing the local population in the company's activities, through a plasma/nucleus ${ }^{25}$ model of land tenure that is common in Indonesia.

Companies recognise the need to consider human rights, including the right to food, their advocates, and the legal status of indigenous peoples and their access to land in national legislation. Negotiations initiated by the company in Zanegi are therefore conducted using the global terminology 'free, prior and informed consent'. Indigenous rights,

\footnotetext{
${ }^{23}$ The first finalisation of the negotiation took place in 2010. At the time when field studies were conducted in July 2011 and during the time of writing this paper, there were still many unresolved issues.

24 The currency rate at that time was US\$1=IDR 12.500 (Indonesian Rupiah).

${ }^{25} \mathrm{Plasma} /$ nucleus model is a form of compensatory agreement between companies and local communities commonly in Indonesia. It usually means companies allocate up to $30 \%$ of their acquired land back to the local communities for the share of the plasma. Local community's members will work and receive the profit generated by the allocated land.
} 
ideals and discourses are referred to shape and provide 'the direction' for negotiations. The emphasis on indigenous identity is particularly chosen when distributing compensation. Reciprocally, when indigenous people make claims for compensatory arrangements, they are based on indigeneity. Essentially, these claims are an attempt by indigenous peoples to secure access to the resources they need to sustain their daily livelihoods.

Notably, in the Zanegi's struggle against MIFEE, such recognition of indigenous identity and human rights by private actors has not resulted in the rights-holders getting fair and equal compensation. As the procedure for distributing financial compensation is practised arbitrarily outside the formal system of the state, it raises some questions over its integrity in protecting individual and collective land tenures. Further, it has led to confusion and several blunders at grassroots level. The status of each indigenous community and/or person and questions of which group they belong to can become a source of conflict between individuals and clans.

These problems have emerged because the way that the company engaged with the community in Zanegi is premised on the ambition to secure investments through giving arbitrary financial compensation. The invocation of human rights language becomes a utilitarian activity to control and shape the process of the negotiation and therefore protect the company's interests. This is extremely dicey terrain. When using human rights norms to make economic calculations, indigenous people and human rights activists tend to defend their customary practice of negotiation and the appropriateness of technical methods to control the borders of indigenous territory, such as mapping indigenous land for acquiring formal land titles. In turn, it becomes harder to proceed to more progressive actions that can address and challenge the laws, policies and practices that govern having access to food and land at grassroots level.

In general, the case study above demonstrates that a reference to global norms on human rights and the right to food carried out by the intermediate actors can clarify whose rights are being violated (by identifying victims and rights-holders), what the violations are (by elucidating impacts) and which international institutions can address these violations (by giving access to global fora). A pragmatic emphasis on indigenous identity has contributed to making such identification necessary for 'a race to the top'. It establishes a legitimacy for submitting human rights claims to international fora. In 2011, CERD sent a letter to the Government of Indonesia under its Early Warning and Urgent Action Procedure regarding the measures taken to seek free, prior and informed consent from the Malind and other indigenous peoples in Papua. ${ }^{26}$ The case was also included in the second cycle of Indonesian Universal Periodic Review at the Human Rights Council in 2012. ${ }^{27}$

As intermediate actors engage socially with the rights-holders and the rights-holders participate in the formulation of claims, an enabling political environment is created. Important to note here is that this political environment can be considered as different in content and negotiation process from other political environments created by the

\footnotetext{
${ }^{26}$ Letter of 2 September 2011. Information available at http://www2.ohchr.org/english/bodies/cerd/docs/ early_warning/Indonesia02092011.pdf. To date, CERD has not received any responses from the Indonesian Government.

${ }^{27}$ Human Rights Council, Summary prepared by the Office of the High Commissioner for Human Rights in accordance with paragraph 5 of the annex to Human Rights Council resolution 16/21. A/HRC/WG.6/13/IDN/ 3, 9 March 2012, para. 58. The UPR review pertaining to the case of Papua in general was denied by the Indonesian Government.
} 
invocation of human rights in the light of historical and political considerations surrounding the intricate relationship between Jakarta (Java) and Papua (Chauvel and Nusa Bhakti 2004). Although it would be imprudent to neglect those considerations, this political environment corresponds to the transformative ideals of human rights, as it establishes an opportunity for the dialogue necessary to achieve institutional reforms in the governance of access to food and land for indigenous peoples.

The paradox is that at the same time a pragmatic stance that curbed the invocation of human rights has limited the scope of what is being negotiated and has not served as a political exercise to reinterpret and expand the value of the norms. Inadequate attention is given to claims directed at challenging power hierarchies and institutional structures. In other words, the struggles have not resulted in discursive practices nor engendered dialectical spaces to contest laws, policies and practices that continue to marginalise indigenous peoples of Merauke, Papua, in development processes.

The examination of the case study on the acquisition of indigenous land in Zanegi village by Selaras Inti Persada Inc. suggests that three factors can explain this lack of attention to claims that challenge power hierarchies and institutional structures. First, there is an unequal competition between actors at the grassroots level, which results in contestations of claims and more importantly ambiguities over who has the obligation to protect, respect and fulfil the right to food of the Marind. Second, socio-cultural considerations are used by powerful, private and local actors to expand and protect vested interests. Third, framing the lack of access to food and land for indigenous peoples in Merauke as a violation of human rights has weakened the possibility of making effective claims on, among other things, autonomy and self-rule, and the fair distribution of benefits.

With the growing expansion of human rights norms, public and private actors are increasingly invoking human rights to legitimate their operations. The line between violations and obligations become blurred as rights, obligations and their interpretation converge with powerful interests. The identification of victims, impacts and fora to submit these claims are ineffectual in comparison with the social demarcations that extend and attenuate these powers. The caveat here is that the configuration of actors in negotiating global human rights in practices, apart from the political environment it creates and facilitates, can also become simply a subdued network.

Therefore, in order to assess the transformative potential of human rights and the right to food in particular, it is necessary to ask critical questions about political hierarchies and the relationship between the state and private actors. This involves reengaging with the inherently political or politicised nature of human rights. In the case of MIFEE in Merauke, Papua, it is important to consider the oligarchic nature of the Indonesian development process. Further, claiming human rights is not to speak the 'moral truth' to power, rather to confront the structure of power and privilege, and 'natural' or arbitrary hierarchy, and expressively to dispute the socio-cultural manifestations of power relations in everyday life (Goodhart 2013, 32). To achieve the transformative value of human rights practices, actors are compelled to be involved in determining the answers to radical, yet basic, questions on autonomy in political and economic terms. One might need to examine the conditions pertaining to the representation of claims, agencies, and the accountability gap - including that related to that necessary for indigenous peoples to define their own common good-to sustain their 
identity, to foster solidarity and to shift national and regional political discourse on agricultural modernisation.

\section{Concluding Remarks}

The transformative role of the right to food has attracted many human rights advocates and scholars to suggest that human rights have a significant potential impact to act as powerful transnational norms to address the global phenomenon of agricultural modernisation. This paper critically assessed the invocation of human rights and the right to food in struggles against big development projects, such as the one implemented by the government of Indonesia in Merauke Papua. The previous sections have explored the complex challenges of agricultural modernisation and the different ways in which the right to food and human rights are vernacularised.

While acts of negotiations are indispensable for human rights norms to be operationalised and to create the enabling environment necessary to achieve potential transformative objectives, in the vernacular reality of Merauke Papua, the process of translations can render actors to methodical endeavours as well. The objective of reconciling strenuous competition between legal sources and inconsistent political practices contributes to the strategy. The pressure of gaining representative and legitimate responses to the claims constructed through the process may influence this performance. In reality, as shown in the case study, negotiations occupy a certain domain, topic and objective, which reduces the process into a technical identification exercise. The unfortunate consequence of this pragmatic position is that at the grassroots level, this has created an adventurous way of negotiating land rights, financial compensation and basic facilities. Unequal power configurations in everyday life coexist with human rights negotiations. As a result, actors run the risks of depoliticising the process of negotiations, maintaining the concentration of dominance in societies, providing a margin for the state to circumvent and gain absolution for not meeting its obligations.

From the case study of Merauke, Papua, it is clear that vernacularised practices of human rights need to consider: the role of the state in the process, the patterns of sociocultural interactions that set out the political setting, and more importantly other matters actually being excluded in negotiation processes. In the absence of the state and the legal authority in vernacularised processes of human rights negotiations, flexible interpretations with their technical-rational twist will conceivably persist. In turn, responses are likely to continue to rely on moral pressures and state normative commitments, which observably have little impact on instigating change in institutional structures and practices. In this respect, an investigation into how and to what extent certain issues are selected is as important as an examination of what is being avoided by intermediate actors and others in negotiation processes. The latter could disclose the dynamics of power hierarchies that exist in the corresponding community. It may also deliver insights into deadlocks in the dialectical process and causes of persistent occurrences of human rights violations. Since claims on human rights are usually expressed and constructed as a last resort, when people are desperate and determined to do something to transform and improve their situation, progressive and socio- 
culturally informed actions that slot in basic political questions of realising human rights and consider the deficits created from the process of negotiation are crucial.

Open Access This article is distributed under the terms of the Creative Commons Attribution License which permits any use, distribution, and reproduction in any medium, provided the original author(s) and the source are credited.

\section{References}

Aspinall, E. and G. Fealy (2003). Local Power and Politics in Indonesia. Singapore: Institute of Southeast Asian Studies.

Bakker, L. and S. Moniaga (2010). 'The Space Between: Land Claims and the Law in Indonesia'. Asian Journal of Social Science 38.

Baxi, U. (2002). The Future of Human Rights. New Delhi: Oxford University Press.

Brown, W. (1995). States of Injury: Power and Freedom in Late Modernity. Princeton: Princeton Univ. Press Carpenter, K. A. and A. Riley (2014). 'Indigenous Peoples and the Jurisgenerative Moment of Human Rights'. California Law Review 102

Chauvel, R. and I. Nusa Bhakti (2004) The Papua Conflict: Jakarta's Perceptions and Policies. Washington: East West Centre.

Davidson, J. (2009) 'Dilemmas of democratic consolidation in Indonesia'. The Pacific Review 22 (3): $293-310$

Deiniger, K. et al. (2011). Rising Global Interest in Farmland: Can it Yield Sustainable and Equitable Benefits?. World Bank Agriculture and Rural Development. Washington: World Bank.

De Gaay Fortman, Bas (2010). Political Economy of Human Rights: Rights, Realities and Realisation. New York: Routledge.

Goodale, M. (2007) "The Power of Right(s): Tracking Empires of Law and New Modes of Social Resistance in Bolivia (and elsewhere)." in Goodale, M., and Merry, S.E., (eds.), The Practice of Human Rights: Tracking Law Between the Global and the Local. Cambridge: Cambridge University Press.

Goodhart, M. (2013). 'Human Rights and the Politics of Contestation' in Mark Goodale ed. Human Rights at the Crossroads. Oxford: Oxford University Press.

Golan, D. and Z. Orr (2012). 'Translating Human Rights of the Enemy'. Law and Society Review 46(2).

Hadiprayitno, I. (2010). 'Declared, Not Acquired: Claiming Hunger as A Violation of the Right to Food, with a Case Study from Indonesia'. In Otto Hospes \& Irene Hadiprayitno. Governing Food Security. Law, Politics and the Right to Food. Wageningen: Wageningen Univ. Pub.

Hadiz, V. (2004). 'Decentralization and Democracy in Indonesia: A critique of Neo-Institutionalist Perspectives', Development and Change 35 (4).

Hale, C.R. (2002). 'Does Multiculturalism Menace? Governance, Cultural Rights and the Politics of Identity in Guatemala,'Journal of Latin American Studies 34.

Keck, M.E., \& K. Sikkink (1998) Activists Beyond Borders: Advocacy Networks in International Politics. Ithaca and London: Cornell Univ. Press.

Kennedy, D. (2002). 'International Human Rights Movement: Part of the Problem?' Harvard Human Rights Journal 15.

(2004). The Dark Sides of Virtue: Reassessing International Humanitarianism. Princeton: Princeton Univ. Press.

Levitt, P. and S. E. Merry (2009). 'Vernacularization on the ground: local uses of global women's rights in Peru, China, India and the United States'. Global Networks 9(4)

Merry, S.E. (2006). 'Transnational Human Rights and Local Activism: Mapping the Middle'. American Anthropologist 108.

Mechlem, K. (2004). 'Food Security and the Right to Food in the Discourse of the United Nations'. European Law Journal 10(5).

Meister, R. (2002). 'Human Rights and the Politics of Victimhood'. Ethics \& International Affairs 16(2).

Morgan, R. (2009) Forging Indigenous Rights at the United Nations: A Social Constructivist Account. In R. Morgan and B. Turner. Interpreting Human Rights: Social Science Perspectives. New York: Routledge.

Mowbray, J. (2007). 'The Right to Food and the International Economic System: An Assessment of the Rights-Based Approach to the Problem of World Hunger'. Leiden International Law Journal 20.

Obidzinski, K. et al. (2013). 'Can large scale land acquisition for agro-development in Indonesia be managed sustainably?', Land Use Policy 30 
Rajagopal, B. (2003). International Law from Below: Development, Social Movements and Third World Resistance. Cambridge: Cambridge Univ. Press.

(2005) 'Limits of Law in Counter-Hegemonic Globalization: The Indian Supreme Court and the Narmada Valley Struggle,' in de Sousa Santos, B., \& C. Rodriguez-Garavito, eds., Law and Globalization from Below: Towards a Cosmopolitan Legality. Cambridge: Cambridge Univ. Press.

Risse, T. et al., eds. (1999) The Power of Human Rights: International Norms and Domestic Change. Cambridge: Cambridge Univ. Press.

Sumardjono, M (2012). ‘Pragmatism UU Pengadaan Tanah'. Kompas 7 June 2012.

Topidi, K. and L. Fielder (eds). Transnational Legal Processes and Human Rights. Surrey: Ashgate Publishing Ltd

Widjojo. M.S. (ed) (2010) Papua Road Map: Negotiating the Past, Improving the Present, Securing the Future. Jakarta: LIPI.

Zakaria, R.Y, et al. (2011) MIFEE Tak Terjangkau Angan Marind. Jakarta: Pusaka. 